Mario Stipančević

Croatian State Archives in Zagreb

mstipancevic@arhiv.hr

ORCID: 0000-0002-4451-7699
Data przesłania tekstu do redakcji: 10.06 .2020

Data przyjęcia tekstu do druku: 03.09.2020

\title{
The "Custodial Period" of the Royal Land Archives in Zagreb Through the Activities of Ivan Bojničić and Emilij Laszowski
}

\begin{abstract}
Stipančević Mario, The "Custodial Period" of the Royal Land Archives in Zagreb Through the Activities of Ivan Bojničić and Emilij Laszowski. "Poznańskie Studia Slawistyczne" 19. Poznań 2020. Publishing House of the Poznań Society for the Advancement of the Arts and Sciences, Adam Mickiewicz University, pp. 291-307. ISSN 2084-3011.

The development of Croatian archival science is inextricably linked with the activities of the Royal Land Archives in Zagreb. Although the beginnings of the care of archival materials can be traced back to the middle of the $17^{\text {th }}$ century, it is difficult to talk about organized and systematic protection until the end of the $19^{\text {th }}$ century and the work of two prominent social officials, historians and archivists, namely Ivan Bojničić and Emilij Laszowski. Through their efforts in the next three decades, i.e. until the 1920 s, the Land Archives was transformed into a significant institution with a permanent scientific journal and newly renovated spaces built according to the standards of the archival profession, for the preservation, protection and use of archives. This period, however, was also characterized by the complete absence of theoretical considerations of archival science. According to social, political and financial circumstances, it was necessary to think about the elementary preservation of archival materials to save them from complete decay. Due to all the above, the mentioned period in the development of the Zagreb Land Archives can justly be called "custodial."
\end{abstract}

KeYwords: Royal Land Archives in Zagreb; Emilij Laszowski; Ivan Bojničić; archival activity

\section{Introduction}

The development of archives and archival science in Croatia, to a large extent, at least in the very beginning, can be identified with the development of the central Royal Land Archives in Zagreb, which followed the development line of archives in the entire Habsburg Monarchy. After the first phase, in which archival materials were kept by the creators themselves, 
in the middle of the $19^{\text {th }}$ century began the systematic establishment of institutions that collected and kept archives of various, both official and private provenances. Since the aim here is not to provide a comprehensive historical overview of the development of Croatian archives and archival science, in the following text attention will be paid only to significant events in this process.

Works on the early period of development of the Croatian archival profession are relatively rare. All of them worth mentioning are pointed out below, so there is no need to list them here. In this context, however, it should be noted that the exposition of the theoretical foundations of Croatian archiving in the observed period is almost impossible, since the care of the first Croatian archivists, as the title of the paper indicates, was reduced exclusively to collecting and protecting archival material and only secondary to other components of modern archival practice, such as arranging materials, making finding aids and giving archival materials for use to the broader community. In other words, the theoretical patterns required for the initial establishment of archival practice were more than rudimentary. Finding, listing and protecting archival materials scattered throughout the province in often catastrophic conditions needed a basic intuitive inclination to protect the written cultural heritage, enthusiasm and a lot of effort - all that was more than characteristic of the founders of the domestic archival tradition.

Precisely because of the mentioned intention of this paper, it is necessary to present the circumstances in which the activity of the Zagreb Land Archives developed and to bring closer the conditions in which the Croatian archival profession was founded. Two prominent intellectuals and public figures played a unique role in this: Ivan Bojničić and Emilij Laszowski. In order to make the rest of the paper clearer to the readers, what follows is a brief reference to each of them by recording the essential information from their well-intertwined professional lives.

$* * *$

Historian and archivist Ivan Bojničić was born in Valpovo in 1858. He finished elementary school and lower grammar school in Osijek and continued his education in Budapest, wherein in 1876 he enrolled in law 


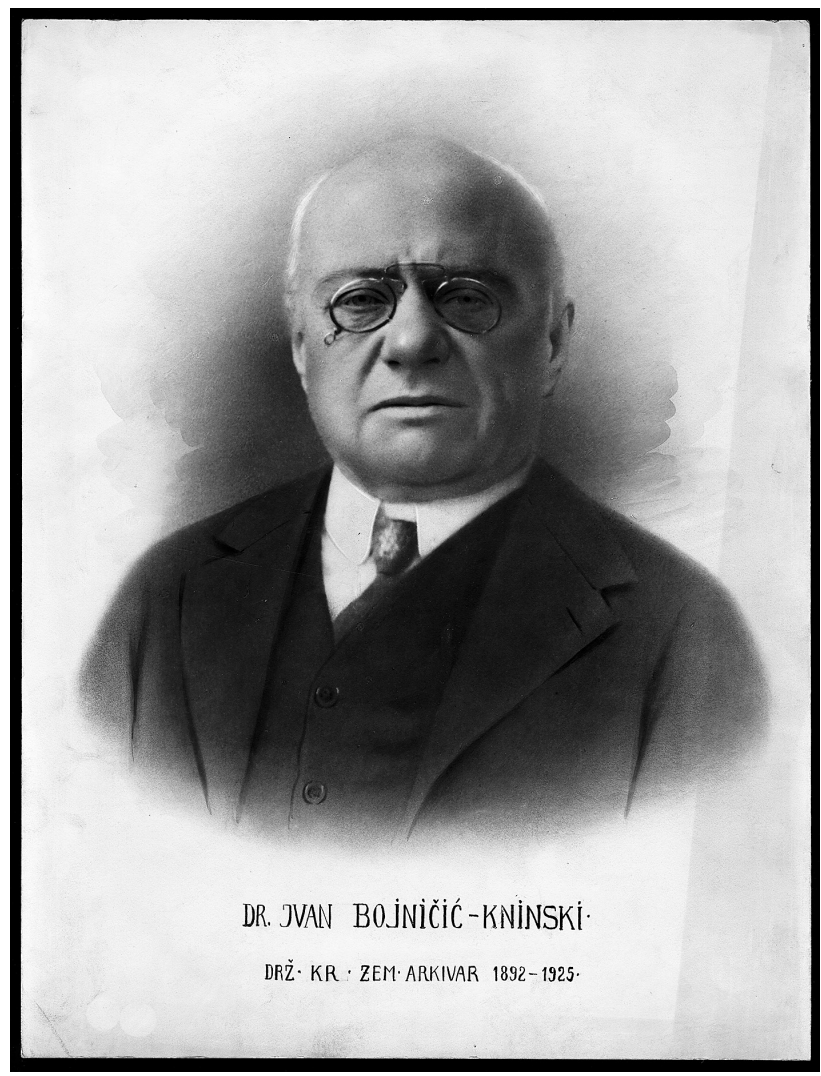

Fot. 1. Ivan Bojničić (HR-HDA-1443. Collection of Photographic Portraits of the $19^{\text {th }}$ and $20^{\text {th }}$ Centuries, no 42 ).

and philosophy. In 1879 he was appointed a member of the archaeological department of the National Museum in Zagreb, and a year later he received his doctorate with the thesis Forgery of documents in the Middle Ages. In 1882 he became a foreign-language instructor of the Hungarian language at the Faculty of Philosophy in Zagreb. He was also active in politics as a Member of Parliament for the People's Party from 1887 to 1889 . He was appointed archivist of the Land Archives in Zagreb in 1892, and he held this position, as well as that of the director until his death in 1925. As the 
head of the Archives he began with its planned development, and in 1913 the Archives was moved to the east wing of the newly built University Library on the Marulić Square (Matijević, 2008, 569-584).

Although in 1885 he was appointed a member of the committee for the organization of the Land Archives, Bojničić was still more a historian than an archivist. His broad scientific interest ranged from political history and the history of the nobility to genealogy and numismatics (Matijević, 2008, 571). However, his greatest passion was dealing with heraldry, to which he dedicated most of his professional career. That is why he is still considered one of the most important Croatian heralds (Galović, 2009, 114). The fact that during his management the Archives succeeded to become an organized and modern cultural and scientific institution was more the result of conscientious organizational work and less of a direct involvement in archival affairs. As for the narrowly professional archival activity, in Bojničić's case, it was reduced to writing only a few small contributions from archival and auxiliary historical sciences, which mainly dealt with the history of archival institutions or describe the materials kept in them (Lučić, 1999, 19; Bojničić, 1899a, 34-40; 1899b, 209-230; 1901, 153-156). There was little direct work on rescuing, evaluating and listing the archives. This is not surprising, because the mentioned tasks did not fall within the functions of the director of the central archival institution.

Emilij Laszowski, archivist, historian and cultural worker, was born in Brlog na Kupi in 1868. A son of an Austro-Hungarian officer, on his father's side he was a descendant of the Polish Laszowski Szeliga family, and on his mother's, the German Šufflay family. He was educated privately and took his exams at the Karlovac and Zagreb grammar schools from 1877 to 1882 , and afterwards attended the Zagreb Classical Gymnasium in the period 1883 to 1887 . He studied briefly at the Faculty of Medicine in Graz, then at the Faculty of Law and State Studies in Zagreb 1888-1893. In 1891 he got a job at the Land Archives in Zagreb and worked there as an archivist from 1893 to 1924, and as the director from 1925 until his retirement in 1939. For a short time during 1941 he was the director of the newly established War Archives and Museum of the Independent State of Croatia in Zagreb. In 1899, together with Ivan Bojničić, he started the journal entitled Vjetsnik Kr. hrvatsko-slavonsko-dalmatinskog zemaljskog arkiva and edited it from 1926 to 1939 . It was on his initiative in the years 1911 to 


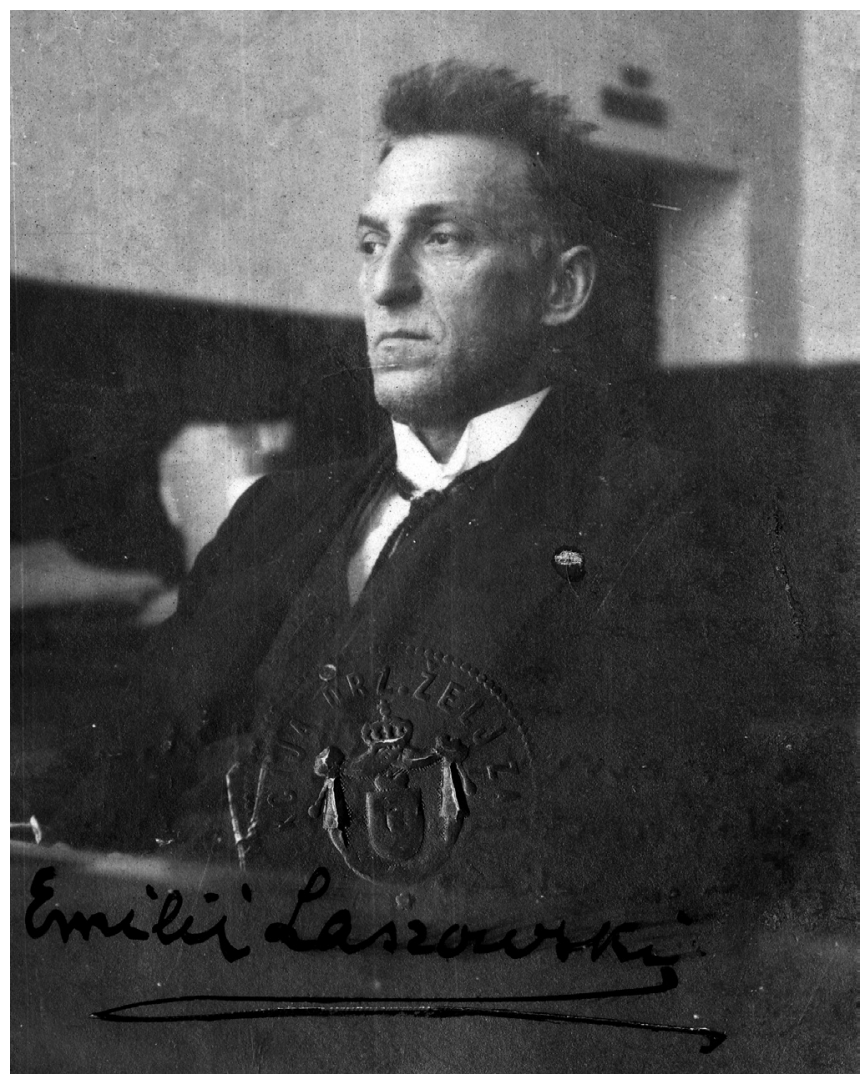

Fot. 2. Emilij Laszkowski (HR-HDA-806. Emilij Laszowski’s Personal Papers, 1.1.10).

1913 that the east wing of the newly built University Library on Zagreb's Marulić Square was reserved for the Land Archives, previously located in an inappropriate area of the Upper Town's Viceroy Palace. In public life he was best known for his work in the Society "Braća Hrvatskoga Zmaja," in which from 1907 to 1909 he initiated the founding of the Zagreb City Archives, the City Museum, the City Library and the Rescue Society. He died in Zagreb in 1949 (Stipančević, Mandušić, 2013, 573-575).

During almost half a century of activity in the Land Archives, he worked on rescuing and collecting archival material, publishing sources 
and institutionalizing the archival profession. He tried to encourage the sensibility of public bodies and private individuals towards archival content, emphasizing that the work on its storage, evaluation and extraction must be conducted exclusively by experts, who should direct the interest of potential researchers and end-users (Lučić, 2016, 77).

Contributions on the field of archival profession that he published in that period, as well as in Bojničić's case, deal mainly with the structure and development of the National Archives and the materials housed in it (Laszowski, 1894; 1898; 1899; 1900; 1907; 1909a; 1909b; 1910a; $1910 b ; 1939 ; 1941 a ; 1941 b)$. Theoretical works from this field were utterly omitted.

\section{Foundations of Croatian archival profession}

It is a common view that the embryo of the central archives was the decision of the Croatian Parliament from 1643 to make a chest (Cista privilegiorum Regni Sclavoniae) in which the privileges of the Kingdom of Croatia, Slavonia and Dalmatia would be kept, i.e. state legal documents of great importance for the defence of Croatian municipal rights (Pandžić, 1993, 7-9; Karaman, 1993, 24).

Although until the $19^{\text {th }}$ century there were still attempts to systematically collect and preserve the most important historical documents, initiated primarily by the Parliament, only in 1848 did the real institutional outlines of the Land Archives of the Kingdom of Croatia, Dalmatia and Slavonia appear. At the same time, the authority over the institution was changed, so that unlike the former "Archiv Regni," which acted as an institution of the Parliament, the Land Archives passed into the scope of executive bodies (Viceroy Council, Government and Governorship). Since that time, the Archives has gradually acquired the features of archives in the modern sense of the word, so it no longer kept the material exclusively created by the Parliament, but became an institution where files created by various creators were collected and preserved. This feature also gave it a fundamental element of the central archival institution in Croatia (Kolanović, 2003, 97-98).

This situation was prompted by the national revival and political events 
that led to the severance of Croatia's ties with Hungary and the increased need to further determine the state and legal foundations of these proceedings by collecting and studying archival materials. At that time, primarily through the work of Ivan Kukuljević Sakcinski, who was appointed a national archivist in 1848, a multitude of materials was returned to Croatia, which was its property due to their origin and functional and historical affiliation. Unfortunately, after the re-establishment of state-legal relations within the framework of the Croatian-Hungarian settlement in 1868, the most significant part of these files was again taken to Budapest in 1885 (Kolanović, 2003, 99).

From the middle of the $19^{\text {th }}$ century the central activity related to the Land Archives became acquiring the sources for the Croatian history due to their publication and storage in the central archival institution. Consequently, settling the issue of transforming the archives into an independent institution was initiated. At the same time, the fundamental questions regarding archiving and archival service of the $19^{\text {th }}$ century (and later) began to be asked. They referred to providing adequate space, professional staff, making a list of archives and the creation of an archival library (Kolanović, 2003, 100).

It was at the suggestion of the historian, politician and national revivalist I. Kukuljević Sakcinski that in 1852 the ban (viceroy) approved the employment of three officials, who began work on listing and cataloguing the material at the Archives. At that time, financial resources were provided and the premises in which the Archives was located were put in order. (Karaman, 1993, 26-28). Also then, the first finding aids were created, the first archival boxes for technical equipment of materials were procured and the foundations of the archival library were laid by purchasing palaeographic and diplomatic manuals and a collection of the Kingdom laws (Kolanović, 2003, 102).

The Archives has since become inextricably linked with historiography as a scientific discipline. This connection, in which the activity of archives was in the function of the scientific study of the past, and archival science only an auxiliary historical discipline, prevailed for the next hundred years. The basis of such an approach to archival materials was reduced to the issue of its collection, protection (custodiae), and preservation (conservationis), so the mentioned period in the development of the archival 
profession, in which all care was focused exclusively on conservation, is often called "custodial." As it is well known, in contrast to this approach, modern archival principles try to shape archives and the archival service not only as custodians of material, but also as information intermediaries that support other institutions in managing their information sources. Archives, in other words, have become places to study "everything," from identity to family roots, not just history in the narrow sense.

One of the central issues related to the Land Archives in the second half of the $19^{\text {th }}$ century was its legal organisation. Although attempts to enact a legal basis had existed since 1865, until the regulation of relations between Croatia and Hungary the proposals failed to obtain the King's sanction. One of the reasons was the fact they stated that the Land Archivist should be appointed by the Parliament at the recommendation of the Academy, and not of the viceroy as prescribed by the Law on the Organization of the Land Archives in Zagreb from 1870 (Stulli, 1997, 78-80).

Simultaneously with this, there was a discussion on the use of archival materials and acquisition policy. Namely, a select parliamentary committee had to discuss the use of archival material and prepare a decree on the use of documents as a supplement to the Act. The proposal of the parliamentary committee from 1866 spoke about the use of materials, the oath of the land archivist and instructions for collecting archives. (Kolanović, 2003, 109-110; Stulli, 1997, 85-88).

Although these proposals did not receive confirmation from the King, it can be argued that they directed the archival activity to some extent and that these instructions were followed in the regular conduct of archival activities even after the adoption of a brief legal basis on the Land Archives in 1870 . The attempt to make the idea on centralising the archives into a reality was repeated in 1875, at the same time as the Senate of the University of Zagreb requested the opening of a position for a professor who would simultaneously work at the University and teach auxiliary historical sciences (Kolanović, 2003, 110). Unfortunately, neither request was met and the Land Archives remained alive at the far end of the Croatian scientific and cultural institutions of the time. 


\section{Protection and storage}

The situation that Laszowski and Bojničić found when they arrived at the Archives was genuinely catastrophic. The premises in the Viceroy Palace, the building in which the Land Government was also housed, were utterly dilapidated, with no underlying conditions for the accommodation, storage or use of archival materials. Moss grew on their walls; the windows were permeable, old and dilapidated, without curtains and exterior glass, protected only by iron bars and wooden boards.

For this reason, less than a year after his employment, in mid-1892, Laszowski requested the most basic rehabilitation of the space, without which the Archives could not serve its purpose. Stressing that these were urgent interventions, he asked for the purchase of double windows and curtains for better protection from the weather, repair and painting of the wooden floor, painting the walls, installing new office stoves and archival rooms for better document protection, making cabinets for files, etc. Although the funds for the requested repairs would not be excessively high, according to the preserved information, the Land Government turned a deaf ear to most of them (Stipančević, 2014, 68-69).

After the arrival of Bojničić as the director of the Land Archives, special efforts were made to arrange the dilapidated archival premises. In 1895, on their joint initiative, a storage room and an office with a corridor and a toilet were arranged. At the same time, about 1,000 suitable cardboard boxes were procured to accommodate the materials. Accordingly, the Directorate of Archives proposed to the authorities the continuation of repairs of the second archival storage room and further procurement of archival boxes. This was done in 1896, when the renovation of the old corridor was completed, the second storage room was repaired and decorated, and new shelves were made for the storage of archival materials (Stipančević, 2014, 69-70).

Minor repairs and half-baked solutions lasted for almost two decades, until in 1913, thanks to Laszowski's friendly and family ties with the then viceroy Nikola Tomašić, the Land Archives was housed in a purposebuilt building of the Royal University Library and the Land Archives (Stipančević, 2013, 183-186).

Archival materials were in no better shape. Bojničić and Laszowski were well acquainted with the decline of precious files in the Croatian 


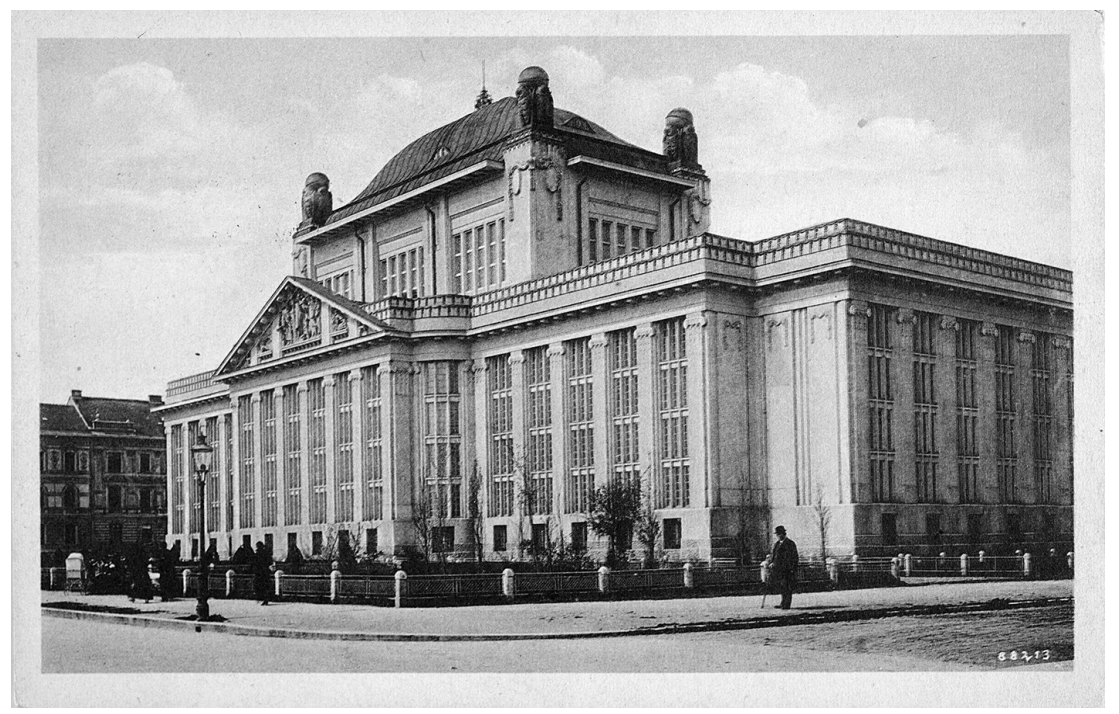

Fot. 3. The building of the University Library and the Land Archives (today the Croatian State Archives) (HR-HDA-1684. Postcard Collection, Zagreb-131).

province. Sensitivity to the preservation of written historical heritage, with rare exceptions, was almost non-existent. The legal provisions prohibiting the destruction of archival materials were not known to the competent provincial authorities, nor did they comply with them. In such conditions, the first and fundamental task of the then archival service was to save everything that could be saved, mostly by transfer to the Zagreb Land Archives. In this way, since 1895 hundreds of meters of archival materials had been delivered to Zagreb through purchases, takeovers ex officio and donations.

Hence, during 1895 the Land Archives came into the possession of the archives created by the famous noble Rattkay family, and another batch of their papers was handed over to the Archives nine years later (Stipančević, 2014, 117-118). During 1897 activities were undertaken in Vukovar, the seat of the Srijem County, to protect and take over/acquire the local archival materials. The work that Laszowski had to do there illustrates well how Croatian archivists were forced to act in the late $19^{\text {th }}$ and early $20^{\text {th }}$ century. The material of the Srijem County was neglected, although it was a part of the state administration that had to be acquainted 
with the legal provisions on the preservation and protection of registry and archival materials. The oldest writings were a huge mess scattered in several dark, inaccessible and damp places, and one part was housed in an outbuilding where stables and drought were located. Thick dust and mould were deposited on the files, while those placed on the lower rows of shelves were damp from the water that erupted from the floors, so it was necessary to ventilate and dry them in the sun. A large part of these archives could not be saved because they were completely rotten due to moisture. After dusting and drying, the files were arranged chronologically, according to the ordinal number in the protocols, i.e. registration records, and then placed in appropriate bundles, which were correctly marked (Stipančević, 2014, 120-121).

The Archives sought to increase the scope of the material in all possible ways. That is why it often collaborated with Zagreb antique shops, such as in 1899 when it bought 437 documents from the $15^{\text {th }}$ to the $19^{\text {th }}$ century from the antiquarian M. F. Strmecki. In that sense, the cooperation of the Land Archives with the famous Zagreb antiquarian Mirko Breyer should be mentioned, from which valuable archives had also been purchased on several occasions. In 1904 Breyer sold a collection of old originals and transcripts of various documents and aristocratic papers from the $9^{\text {th }}$ to the $19^{\text {th }}$ century, and the collaboration continued in 1905 and 1907 with three more purchases, mostly valuable medieval and early modern documents (Stipančević, 2014, 125).

The documents of the noble Galliuff family also reached the Archives on two occasions, in 1900 and 1902. This acquisition preserved valuable materials related to the management of the family's estate from 1610 to 1887 , especially public documents, lawsuits and correspondence of its members. Soon the holdings were enriched by 37 certificates of the nobility of various Croatian families purchased from a private owner (Stipančević, 2014, 125-126).

The following year, 1903, the Directorate managed to enter into negotiations with the representatives of Prince Albert Thurn and Taxis regarding the acquisition of material important for the Croatian history from several manorial archives in his possession. Although they were quite long and exhausting, they were successfully completed at the end of 1909, when the most valuable documents created from 1567 to 1891 were donated to 
the Land Archives by Prince Thurn and Taxis, reserving the right to use them in case of need (Stipančević, 2014, 126-127).

In 1903, five years after beginning the processing the counties' archives, the Directorate of the Land Archives did the same with the archives of the Zagreb County, which was also on the verge of decay. Although it was in Zagreb's Upper Town, in the immediate vicinity of the then location of the Land Archives, the activities undertaken at the time did not help to improve its condition. Nevertheless, the mentioned action encouraged other great county prefects to take care of the condition of their registry offices. Thus, in 1905 the great prefect of Bjelovar-Križevci County asked the Directorate for an expert assessment, arrangement and protection of the local archives, which was done during the following year. Due to the work of arranging the archives and the possible collection of materials for writing its history at the beginning of 1906, the Virovitica County, and a little later the Rijeka-Modruš County, also contacted the Directorate of the Land Archives. However, over time, it turned out that this indirect form of supervision of the central archival institution over the valuable material of county archives did not give the desired results, due to lack of funds and professional staff, so as the inertia of county authorities and it was soon given up. Difficulties regarding arranging and protecting county archives were only removed by their takeover into the Land Archives, for which it was necessary to wait another fifteen years (Stipančević, 2014, 129-132).

During 1910 a significant part of the collection of archival and book material of the Trogir Fanfogna-Garagnin family was taken over by the Land Archives. Although in the end it turned out that the most important documents of that family archive were sold, more than a hundred papers and old manuscripts were selected, listed and delivered to Zagreb, as well as thirty incunabula and rare books in Latin and Croatian (Stipančević, 2014, 134-136).

Amid the First World War, the Directorate encouraged the takeover of the archives of the Royal Aristocratic Convent in Zagreb, an institution for the education of students of poorer financial situation, founded in 1627, in which many eminent writers, politicians, lawyers and professors received their primary education. Materials of considerable value for the study of Croatian cultural and educational history were taken over by the Land Archives under the mentioned conditions in November 1914. It 
seems that this was the first takeover in which the transfer of material to the Archives was conditioned by modern standards of storage i.e. storing them as a separate archival entity under the name of its creator, listing them in detail so that some of them would not be lost or disappeared over time, and by leaving material that still had a useful value in performing current, administrative, work in the institution where it was created. The rules of the profession today dictate perhaps somewhat more elaborate principles of taking over archival material from either private or legal creators (Stipančević, 2014, 139-140).

In the same year, the Archive launched an even more significant action to enrich its holdings. In mid-1914, the Archdiocese of Zagreb negotiated a contract with the Land Government according to which its archives were stored in the Land Archives for a period of fifty years, while the Metropoli$\tan$ Library of the Zagreb Archdiocese was stored in the University Library for the same period. The contracts stipulated that a special priest, elected by Kaptol (Chapter), would be nominated by the archbishop and appointed by the Government, to perform the service of the Kaptol archivist and the metropolitan librarian (Stipančević, 2014, 140-141).

In the middle of 1917, the Directorate of the Archives initiated an action of studying, selecting and taking over the material at the district courts in Zemun, Srijemski Karlovci, Mitrovica, Glina, Kostajnica, Brinje and Otočac. Due to the vast scope of work, Bojničić, the director of the Archives, was sent to Zemun, Mitrovica and Srijemski Karlovci by the decision of the Government, while Laszowski was to do the work of evaluating and taking over the materials of the district courts in Glina, Kostajnica, Brinje, Otočac and Gospić. The takeover of the material of judicial institutions continued at the end of 1918 when preparations began for the taking over of the content of court in Bjelovar, and specific work of the arrangement started during December 1919 (Stipančević, 2014, 147).

After the end of the First World War, Bojničić and Laszowski were involved in negotiations on the distribution of the archival property of the former state. Unfortunately, most of the documentation on these tasks is lost, so one can only speculate about the extent of their activities. It is quite certain that the Directorate intended to do everything in its power to return the archival materials originating in Croatia to where they belonged according to all the laws of the time, as well as modern ones. The 
results, however, were devastating. The vast majority of the material remained in the institutions in which it was located before the disappearance of the joint state, and these institutions remained the unquestionable property of each country that "physically inherited" them. In that sense, Croatia had lost a large amount of materials of immeasurable importance for its history, without any possibility to dispose of them equally in any way (Stipančević, 2014, 150-151).

The fact that little attention was paid to archival heritage at all levels of state administration at that time is supported by the handing over of documents from the Parliament's Office, which ceased to function after the creation of the Kingdom of Serbs, Croats and Slovenes. Namely, only thanks to the care of one employee, the material created by the National Council of the State of Slovenes, Croats and Serbs from 1918 was collected, arranged and stored in the former Land, now Royal State Archives in Zagreb. In this way, the documents were saved from certain ruin, since some of them were literally taken out of the dustbins and some obtained from the private ownership of former members of the National Council. Of course, only a small amount was saved, because it was already noticed at that time that more than half of the total material of that institution was missing (Stipančević, 2014, 154).

During 1923, the long-standing procedure of taking over the archives of the Zagreb County into the State Archives was renewed. Attempts to place this material under the direct control of the central archival institution in Croatia due to its exceptional historical value and preservation date back two decades. However, this issue was not resolved until mid-1925, mostly due to withholding storage requests or shifting responsibility for surrender to other levels of government.

At that time, the decision of the Zagreb County representatives determined that the archival materials created before 1870 are handed over to the State Archives for storage, while the storage of documents created by the county authorities from 1870 to 1890 depended on the assessment and selection of the Archives' representatives. At the same time, a decision was made to hand over the archives of the Varaždin County to the State Archives and agreed to do so with the archival materials of the Bjelovar-Križevci, Virovitica, Srijem, Požega, Lika-Krbava and Primorje-Rijeka counties (Stipančević, 2014, 154). 
These takeovers were also the last tasks that Bojničić and Laszowski performed together. Namely, in June 1925, when Bojničić died after a long illness, Laszowski was appointed for the temporary management of the State Archives. By the royal decree of November 1925 he was soon appointed director of the institution (Stipančević, 2014, 155), with which began a new period of activity in the institution and care for archival heritage. Younger experts soon joined the Archives, some of them educated in higher archival schools in West Europe, bringing completely new patterns to Croatian archiving, while criticizing their predecessors.

\section{Conclusion}

Due to their tireless and dedicated work and inclination towards historical heritage, Bojničić and Laszowski managed to build a solid foundation for the development of a modern archival profession in Croatia from the "monstrous and most notorious registry," as they once called it. Until their arrival, the Archives was indeed a dilapidated dustbin in which archival materials were laid away unsystematically and without any order. Through the efforts of these two archivists, the institution was painstakingly put in order in the following decades and supplemented with significant additions, so that before the First World War it was moved to its current location, to the then newly built building of the University Library. In addition, because of the activities of Laszowski and Bojničić, the Archives has become more recognizable than ever since its founding with its own newspaper - Vjesnik Kr. hrvatsko-slavonsko-dalmatinskog zemaljskog arkiva - which in 2019 celebrated the $120^{\text {th }}$ anniversary of its publication.

On the other hand, neither became significant archival theorists. Their methodological knowledge was and remained rudimentary, drawn exclusively from fieldwork on the collecting and preserving the written heritage, which literally had to be saved from decay. The overall efforts of the central Croatian archival institution during the thirty-year period at the turn of the $19^{\text {th }}$ to $20^{\text {th }}$ century were based on this "collecting" principle. The fact that it did not keep pace with the development of the archival profession in other, more advanced parts of Europe at the time led to harsh criticisms of the backwardness of Bojničić and Laszowski in 
modern times by younger, educated archivists. These criticisms, as real as they were, were fundamentally unjustified because had Bojničić and Laszowski spent more time writing and discussing the archival theory instead of dealing with it less directly the Croatian written heritage would have been poorer for a significant part of today's holdings, and future archivists would lack a significant part of the basis of their supposedly unavoidable theoretical explanations.

\section{References}

Bojničić, I. (1899a). Listine XII. vieka u zem. arkivu. "Vjestnik Kr. hrvatsko-slavonsko-dalmatinskog zemaljskog arkiva" br. 1, pp. 34-40.

Bojničić, I. (1899b). Škrinja privilegija kraljevine. "Vjestnik Kr. hrvatsko-slavonsko-dalmatinskog zemaljskog arkiva" br. 1, pp. 209-230.

Bojničić, I. (1901). Izvorne plemćke diplome (litterae armales) u kralj. zem. arkivu. "Vjestnik Kr. hrvatsko-slavonsko-dalmatinskog zemaljskog arkiva" br. 3, pp. 153$-156$.

Galović, T. (2009). Hrvatska heraldička periodika: Vitezović i Glasnik heraldike. "Arhivski vjesnik" br. 52, pp. 81-127.

Karaman, I. (1993). Djelatnost Ivana Kukuljevića kao zemaljskog "arhivara” (1848-1860). In: Studije i prilozi iz arhivistike. Ur. J. Kolanović. Zagreb: Arhiv Hrvatske, pp. 23-32.

Kolanović, J. (2003). Institucionalizacija arhivske službe u Hrvatskoj u drugoj polovici 19. st. In: Stjepanu Antoljaku u čast. Ur. J. Kolanović. Zagreb: Hrvatski državni arhiv, pp. 97-98.

Laszowski, E. (1894). Hrvatski zemaljski arhiv. U spomen stogodišnjice njegovog obstanka. "Prosvjeta" br. 6-8, pp. 184-186; 215-220; 248-250.

Laszowski, E. (1898). Arkivi u županiji srijemskoj. "Starine” br. 29, pp. 1-11.

Laszowski, E. (1899). Kr. hrvat.-slavon.-dalmat. zemaljski arkiv. "Vjestnik Kr. hrvatsko-slavonsko-dalmatinskog zemaljskog arkiva" br. 1, pp. 4-20.

Laszowski, E. (1900). Stečevine kr. zemaljskog arkiva g. 1899. "Vjestnik Kr. hrvatsko-slavonsko-dalmatinskog zemaljskog arkiva" br. 2, pp. 121-122.

Laszowski, E. (1907). Bilješke iz c. kr. drž. Financijalnog arkiva u Beču. "Vjestnik Kr. hrvatsko-slavonsko-dalmatinskog zemaljskog arkiva" br. 9, pp. 176-194.

Laszowski, E. (1909a). Iz našeg kr. zem arkiva (Arch. Sermage). "Hrvatstvo" br. 210, p. 3.

Laszowski, E. (1909b). Znatna stečevina u kr. zem. arkivu. "Narodne novine" br. 292, pp. 3-4.

Laszowski, E. (1910a). Historia et praesens status archivi regnor. Croatiae, Slavoniae, et Dalmatiae. Zagreb: Typis typographie regnicolaris. 
Laszowski, E. (1910b). Kamo da se spremi naš zem. arkiv. "Narodne novine” br. 103, p. 7.

Laszowski, E. (1939). Zagrebački gradski arhiv. "Zagreb” br. 7, pp. 225-232.

Laszowski, E. (1941a). Arhiv bivše hrvatske "Generalkomande”, najvažniji vojnički arhiv u Hrvatskoj. "Hrvatski narod" br. 115, p. 12.

Laszowski, E. (1941b). Ratni arhiv i muzej Nezavisne Države Hrvatske. "Hrvatski narod" br. 122, p 8.

Lučić, M. (1999). Arhivistika kroz sto godina Arhivskog vjesnika. "Arhivski vjesnik" br. 42, pp. 17-28.

Lučić, M. (2016). Laszowski i hrvatsko arhivsko naslijeđe. In: Stoljeće nakon Laszowskog. Zbornik radova sa znanstveno-stručnog skupa. Ur. M. Stipančević. Zagreb: Hrvatski državni arhiv, pp. 77-91.

Matijević, Z. (2008). Dr. Ivan pl. Bojničić (1858.-1925.). U prigodi 150. obljetnice njegova rođenja. "Arhivski vjesnik" br. 51, pp. 569-584.

Pandžić, M. (1993). Povodom 350. obljetnice izrade škrinje povlastica/sloboština Arhiva Kraljevstva Hrvatske (1643-1993). “Arhivski vjesnik” br. 36, pp. 7-21.

Stipančević, M. (2013). Na kavi s banom - pozadina izgradnje zgrade Sveučilišne knjižnice i Zemaljskog arhiva u Zagrebu. “Arhivski vjesnik” br. 56, pp. 173-189.

Stipančević, M. (2014). Neznani svijet Emila Laszowskog. Zagreb: Hrvatski državni arhiv.

Stipančević, M., Mandušić, I. (2013). Laszowski, Emilij. In: Hrvatski biografski leksikon (Kr-Li). Sv. 8. Ur. T. Macan, Zabreb: Leksikografski zavod Miroslav Krleža, pp. 573-575.

Stulli, B. (1997). Zakon o uređenju zemaljskog arhiva u Zagrebu iz godine 1870. In: Arhivistika i arhivska služba. Studije i prilozi. Ur. J. Kolanović. Zagreb: Hrvatski državni arhiv, pp. 78-97. 